\title{
ANALISIS YURIDIS AKTA PERJANJIAN PENGIKATAN JUAL BELI YANG OBJEKNYA MERUPAKAN HARTA BERSAMA (Studi Kasus Putusan Pengadilan Negeri Sleman Nomor 221/Pdt.G.2019/Pn.Smn)
}

\author{
Alifa Permata Adiani \\ (Universitas Gadjah Mada, Indonesia, alifa.permata.adiani@mail.ugm.ac.id)
}

\begin{abstract}
This study aims to determine and analyze the validity and legal consequences of a sale and purchase binding agreement whose object is joint property, the notary's responsibility for the deed made before him and the form of legal protection for buyers who have good intentions in a sale and purchase binding agreement whose object is joint property. This type of research is an empirical juridical research. This research is descriptive and analyzed using qualitative methods. Based on the results of the analysis, it was concluded that the Agreement Letter made under the hand between the seller in the Sale and Purchase Binding Agreement with his former married partner in which the letter was deposited with a Notary domiciled in Banyumas Regency as stated in the Van Depot Deed, is legally valid as a basis the seller's acting authority to transfer the object of joint property in the sale and purchase binding agreement. For a deed made by or before a notary, the notary has civil, criminal and administrative responsibilities. However, the responsibility of a Notary follows the principle of responsibility based on error.
\end{abstract}

Keywords: Notary Deed, Sale and Purchase Agreement Deed, Common Property

\begin{abstract}
Abstrak
Penelitian ini bertujuan untuk mengetahui dan menganalisis keabsahan dan akibat hukum perjanjian pengikatan jual beli yang objeknya merupakan harta bersama, pertanggungjawaban notaris terhadap akta yang dibuat di hadapannya serta bentuk perlindungan hukum terhadap pembeli yang beritikad baik dalam perjanjian pengikatan jual beli yang objeknya merupakan harta bersama. Jenis penelitian ini adalah penelitian yuridis empiris. Penelitian ini bersifat deskriptif dan dianalisis menggunakan metode kualitatif. Berdasarkan hasil analisis, diperoleh kesimpulan bahwa Surat Perjanjian yang dibuat dibawah tangan antara pihak penjual dalam Perjanjian Pengikatan Jual Beli dengan mantan pasangan kawinnya yang mana surat tersebut dititipkan kepada Notaris yang berkedudukan di Kabupaten Banyumas sebagaimana yang dinyatakan dalam Akta Van Depot, sah secara hukum sebagai dasar kewenangan bertindak penjual untuk mengalihkan objek harta bersama pada perjanjian pengikatan jual beli. Terhadap akta yang dibuat oleh atau dihadapan seorang notaris maka notaris memiliki tanggung jawab secara perdata, pidana dan administrasi. Meskipun demikian tanggung jawab yang dimiliki oleh Notaris menganut prinsip tanggung jawab berdasarkan kesalahan.
\end{abstract}

Kata Kunci: Akta Notaris, Perjanjian Pengikatan Jual Beli, Harta Bersama 


\section{Pendahuluan}

Dewasa ini, banyak perkawinan yang harus berakhir dengan perceraian. Perkawinan bukan lagi dianggap sesuatu yang sakral sehingga apabila terjadi perceraian maka merupakan hal yang biasa dan bukan merupakan hal yang tabu. Realitanya, Perceraian dapat dijadikan sebagai sarana untuk meningkatkan popularitas oleh kalangan tertentu. Oleh karena itu maka perceraian semakin banyak terjadi tidak hanya di kalangan masyarakat awam, akan tetapi juga banyak terjadi di kalangan masyarakat golongan intelektual. ${ }^{1}$ Adanya putusan perceraian tidak serta merta mengatur mengenai pembagian harta bersama. Dalam suatu perkawinan yang putus karena perceraian sedangkan pasangan tersebut tidak pernah membuat perjanjian pisah harta, maka harus dibuatkan putusan terpisah mengenai pembagian harta bersama yang mereka miliki. Tidak adanya putusan/penetapan mengenai pembagian harta bersama

\footnotetext{
${ }^{1}$ Happy Susanto, 2008, Pembagian Harta Bersama Saat Tejadi Perceraian, Cetakan Kedua, Visi Media, Jakarta, hlm. 1.
}

tersebut mengakibatkan setiap perbuatan hukum terhadap asset-asset yang terdaftar atas nama salah satu pihak, baik itu atas nama suami/istri, maka harus mendapat persetujuan dari mantan suami/istrinya. ${ }^{2}$

Ketentuan mengenai harta bersama dalam perkawinan diatur dalam Pasal 35 Ayat (1) Undang-Undang Nomor 1 Tahun 1974 Tentang Perkawinan ("UUP") yang menjelaskan bahwa harta benda yang diperoleh selama perkawinan menjadi harta benda bersama. Harta benda yang diperoleh selama perkawinan tersebut meliputi segala barang bergerak maupun barang tidak bergerak serta segala keuntungan dan kerugian baik itu yang didapatkan dari usaha maupun upaya yang dilakukan oleh pasangan suami/istri tersebut selama mereka terikat dalam perkawinan.

Pada putusan ini, yang menjadi dasar adanya gugatan dikarenakan Penggugat menyatakan Tergugat I dan Tergugat II

\footnotetext{
${ }^{2}$ Bernandus Nagara, "Pembagian Harta Gono Gini atau Harta Bersama Setelah Perceraian Menurut Undang-Undang Nomor 1 Tahun 1974", Jurnal Lex Crimen, Vol. V, No.7, Sept, 2016, hlm. 51
} 
melakukan suatu tindakan wanprestasi dengan masih menempati objek perjanjian pengikatan jual beli. Tergugat I menyatakan bahwa objek perjanjian pengikatan jual beli antara Penggugat dan penjual merupakan Harta Bersama yang belum terbagi antara Tergugat I dan Penjual. Selain itu Tergugat I juga menyatakan bahwa Penggugat dan penjual membuat perjanjian pengikatan jual beli tersebut tanpa seizin Tergugat I. Namun, Pihak Penjual dalam Perjanjian Pengikatan Jual Beli dalam melakukan perbuatan hukum tersebut telah mendapat persetujuan dari Tergugat I selaku mantan pasangan kawin penjual sebagaimana dituangkan dalam Surat Perjanjian tertanggal 18 Februari 2017 yang mana surat tersebut dititipkan kepada Notaris yang berkedudukan di Banyumas sebagaimana yang dinyatakan dalam Akta Van Depot tanggal 21 Agustus 2018.

Secara gramatikal kata-kata "atas persetujuan bersama" memiliki dua arti, yaitu harus bertindak bersama-sama atau suami/istri dapat memberikan persetujuan/ kuasanya kepada pasangannya. 3 Realitanya dalam masyarakat, bentuk kesepakatan oleh pasangan/ mantan pasngan kawin dapat beragam. Dalam Putusan ini, Penjual menggunakan surat perjanjian dibawah tangan yang dititipkan kepada notaris dan dibuatkan Akta Van Depot sebagai dasar kewenangan bertindak mengalihkan hak atas tanah yang merupakan harta bersama. Berdasarkan uraian ini maka penulis tertarik untuk mengadakan penelitian hukum mengenai “ANALISIS YURIDIS AKTA PERJANJIAN PENGIKATAN JUAL BELI YANG OBJEKNYA MERUPAKAN HARTA BERSAMA (Studi kasus Putusan Pengadilan Negeri Sleman Nomor 221/Pdt.G/2019/Pn.Smn)”

\section{Rumusan Masalah}

Berdasarkan uraian latar belakang di atas, maka permasalahan yang timbul adalah sebagai berikut:

\footnotetext{
${ }^{3}$ Muchlis Patahna, 2009, Problematika Notaris, Rajawali, Jakarta, hlm. 11.
} 
1. Bagaimanakah keabsahan dan akibat hukum akta perjanjian pengikatan jual beli yang objeknya merupakan harta bersama dalam Putusan Pengadilan Negeri Sleman Nomor 221/Pdt.G/2019/Pn.Smn?

2. Bagaimanakah

pertanggungjawaban notaris terhadap akta perjanjian pengikatan jual beli yang objeknya merupakan harta bersama yang dibuat di hadapannya dalam Putusan Pengadilan Negeri Sleman Nomor 221/Pdt.G/2019/Pn.Smn?

3. Bagaimanakah perlindungan hukum terhadap pihak pembeli yang beriktikad baik dalam perjanjian pengikatan jual beli yang objeknya merupakan harta bersama dalam Putusan Negeri Sleman Nomor 221/Pdt.G/2019/Pn.Smn?

\section{Metode Penelitian}

Jenis penelitian ini termasuk pada jenis penelitian yuridis normatif. Penelitian yuridis yaitu penelitian yang menggunakan bahan-bahan hukum, baik bahan hukum primer maupun bahan hukum sekunder. Penelitian hukum normatif adalah penelitian hukum yang dilakukan dengan cara menggunakan pendekatan UndangUndang, kamus, dan konseptual (misalnya asas-asas, pendapat ahli, dan lain-lain) mengenai perilaku anggota masyarakat dalam hubungan hidup bermasyarakat. ${ }^{4}$ Sifat penelitian ini adalah deskriptif yaitu merupakan penelitian yang bertujuan untuk memperoleh gambaran (deskripsi) lengkap tentang keadaan hukum yang berlaku di tempat tertentu yang terjadi dalam masyarakat. ${ }^{5}$ Sesuai dengan jenis penelitian ini maka yang diteliti adalah mengenai keabsahan dan akibat hukum penggunaan akta dibawah tangan yang dibuatkan Akta Van Depot sebagai dasar kewenangan bertindak dalam pembuatan Akta Perjanjian Pengikatan Jual Beli yang

\footnotetext{
4 Soerjono Soekanto dan Sri Mamudji, 2014, Penelitian Hukum Normatif Suatu Tinjauan Singkat,

PT Raja Grafindo Persada, Jakarta, hlm. 1-2.

5 Abdulkadir Muhammad, 2004, Hukum dan Penelitian Hukum, Cetakan ke-1, PT Citra Aditya Bakti, Bandung, hlm. 50.
} 
objeknya merupakan harta bersama, pertanggungjawaban notaris serta perlindungan hukum pihak ketiga yang beritikad baik dengan studi kasus Putusan Pengadilan Negeri Sleman Nomor 221/Pdt.G/Pn.Smn.

Cara pengumpulan data dengan penelitian kepustakaan dan penelitian lapangan. Penelitian Kepustakaan dilakukan dengan studi dokumentasi yaitu dokumen-dokumen atau buku yang berhubungan dengan penelitian. Pengumpulan data dalam penelitian lapangan ini dilakukan dengan teknik wawancara. Wawancara adalah suatu proses interaksi dan komunikasi yang diperoleh dengan hanya bertanya langsung kepada narasumber. ${ }^{6}$ Penelitian ini dilaksanakan di Kabupaten Sleman, Provinsi Daerah Istimewa Yogyakarta (DIY) dengan Analisis deskriptif yaitu analisis data untuk memberikan gambaran atau pemaparan atas subjek dan objek

\footnotetext{
${ }^{6}$ Burhan Ashofa, 2004, Metode Penelitian Hukum, Cetakan ke-4, Rineka Cipta, Jakarta, hlm. 161.
}

penelitian sebagaimana hasil penelitian yang telah dilakukan oleh peneliti. ${ }^{7}$

\section{Hasil Penelitian dan Pembahasan}

1. Keabsahan dan Akibat Hukum Perjanjian Pengikatan Jual Beli Berdasarkan Putusan Pengadilan Negeri Sleman Nomor

\section{1/Pdt.G/2019/Pn.Smn.}

Perjanjian pengikatan jual beli merupakan suatu perjanjian yang berkaitan dengan Buku III KUHPerdata tentang Perikatan (van verbintenissen) yang diatur dalam Pasal 1233 sampai dengan 1868 KUHPerdata. Namun jika merujuk dari beberapa ketentuan yang ada, Buku III sendiri tidak memberikan pengertian secara jelas apa yang dimaksud dengan perikatan. Sebagai perjanjian yang lahir karena kebutuhan dan tidak diatur secara tegas dalam bentuk peraturan perundang-undangan maka perjanjian

\footnotetext{
${ }^{7}$ Ibid, hlm. 183.
} 
pengikatan jual beli tidak mempunyai bentuk tertentu. Hal ini sesuai juga dengan pendapat dari Herlien Budiono, perjanjian pengikatan jual beli adalah perjanjian bantuan yang berfungsi sebagai perjanjian pendahuluan yang bentuknya bebas. ${ }^{8}$ Perjanjian pengikatan jual beli lahir karena realita dalam masyarakat seringkali terdapat beberapa hambatan dalam pembuatan Akta Jual Beli. Terdapatnya beberapa persyaratan baik materiil maupun formil yang ditentukan oleh undang-undang yang berkaitan dengan jual beli hak atas tana akhirnya agak menghambat penyelesaian transaksi dalam jual beli hak atas tanah. Persyaratan tersebut ada yang lahir dari peraturan perundang-undangan yang ada dan ada pula yang timbul sebagai kesepakatan para pihak yang akan melakukan jual beli hak atas tanah.

\footnotetext{
${ }^{8}$ Herlien Budiono, "Pengikat Jual Beli Dan Kuasa Mutlak", Artikel Majalah Renvoi, edisi Tahun I, No 10, Bulan Maret, 2004, hlm. 57.
}

Menurut narasumber Ibu Sagung Bunga Mayasaputri Antara S.H. hakim di Pengadilan Negeri Sleman, Jual beli tanah tidak serta merta selesai dengan peralihan sertipikat hak atas tanah. hal ini dikarenakan peralihan sertipikat hak atas tanah hanya bentuk kepemilikan tanah secara de yure, sedangkan secara de facto berupa penguasaan tanah belum terpenuhi. ${ }^{9}$ Dalam kasus ini Perjanjian Pengikatan Jual Beli yang dibuat antara Penggugat dengan Pihak Penjual merupakan salah satu dari rangkaian proses jual beli sebagai perjanjian pendahuluan. Apabila ditinjau berdasarkan kedudukan perjanjian pengikatan jual beli sebagai perjanjian pendahuluan, untuk menentukan keabsahan perjanjian tersebut perlu dilihat apakah telah memenuhi ketentuan dalam Pasal 1320 mengenai syarat sahnya perjanjian.

\footnotetext{
${ }^{9}$ Ibid.
} 
a. Sepakat mereka yang mengikatkan dirinya

Bila ditinjau berdasarkan syarat sahnya perjanjian, dalam pembuatan Akta Perjanjian Pengikatan Jual Beli ini, telah terjadi suatu kesepakatan yang diberikan secara bebas tanpa adanya paksaan, kekhilafan maupun penipuan. Hal ini dibuktikan dengan Para Pihak dalam Akta Perjanjian Pengikatan Jual Beli hadir di hadapan notaris tanpa memberikan kuasa kepada pihak lain. ${ }^{10}$ Selain itu, menurut narasumber Notaris Mustofa S.H., M.Kn. ${ }^{11}$ Adanya aturan umum dalam pembuatan Akta Perjanjian Pengikatan Jual Beli yang berarti para pihak telah mengetahui

10 Wawancara dengan Tuan $\mathrm{X}$ selaku pihak pembeli dalam Perjanjian Pengikatan Jual Beli yang juga merupakan Pengguggat dalam Putusan Pengadilan Negeri Sleman Nomor 221/Pdt.G/2019/Pn.Smn.

${ }^{11}$ Wawancara dengan Notaris Mustofa S.H. M.Kn pada tanggal 22 Februari 2021 di Kantor Notaris/ PPAT Mustofa, S.H. M.Kn di Jl. Gowongan Lor No.38, Gowongan, Kecamatan Jetis, Kota Yogyakarta, Daerah Isimewa Yogyakarta. mengenai hal-hal pokok dalam perjanjian tersebut.

b. Cakap untuk membuat suatu perjanjian.

Apabila ditinjau berdasarkan ketentuan mengenai kedewasaan sebagaimana diatur dalam UUJN maka dalam perjanjian pengikatan jual beli ini, para pihak telah cakap untuk membuat suatu perjanjian. Hal tersebut dibuktikan oleh para pihak dengan identitas dalam kartu tanda penduduk. Menurut responden, Notaris memiliki kewajiban untuk meminta menunjukkan asli dari identitas yang sah (kartu tanda penduduk, surat izin mengemudi atau passpor) kepada para pihak yang akan membuat suatu perjanjian. identitas inilah yang akan menjadi dasar pertimbangan notaris apakah pihak 
tersebut telah memenuhi ketentuan

cakap hukum. ${ }^{12}$

c. Suatu hal tertentu

Dalam Akta Perjanjian

Pengikatan Jual Beli ini objek jual beli merupakan sebidang tanah beserta bangunan dalam sertipikat hak milik nomor 5489/Sariharjo yang yang terletak di Perumahan Lotus Regency I Tegalsari RT 008/RW 030, Sariharjo, Ngaglik, Sleman. Objek jual beli ini termasuk dalam kriteria benda tidak bergerak sebagaimana dinyatakan dalam Pasal 506 KUHPerdata.

d. Kausa yang halal

Isi perjanjian pengikatan jual beli dalam Putusan Pengadilan Negeri Sleman

${ }^{12}$ Wawancara dengan Tuan Z, Notaris pembuat Akta Perjanjian Pengikatan Jual Beli Pada 6 Mei 2021 di Kabupaten Sleman.
Nomor 221/Pdt.G/PN.Smn ini merupakan kesepakakan para pihak untuk mengadakan jual beli hak atas tanah dan bangunan SHM nomor 5489/Sariharjo. Kesepakatan untuk mengadakan jual beli tanah dan / atau bangunan tidak bertentangan dengan undangundang, kesusilaan dan ketertiban umum.

Selain ketentuan mengenai syarat sahnya perjanjian pada umumnya seperti yang diatur dalam KUHPerdata, ada pula yang perlu diperhatikan notaris dalam pembuatan Akta Perjanjian Pengikatan Jual Beli yang objeknya merupakan harta bersama yaitu adanya persetujuan dari mantan pasangan kawin. Hal ini dikarenakan dalam Pasal 35 ayat (1) UUP dinyatakan bahwa harta benda yang diperoleh selama perkawinan menjadi harta bersama. Maka dari itu 
dalam Pasal 36 ayat (1) diyatakan pula bahwa mengenai harta bersama, suami atau isteri dapat bertindak atas persetujuan kedua belah pihak.

Berdasarkan hasil wawancara dengan responden, 13 Realitanya bentuk persetujuan mantan pasangan kawin guna pembuatan akta otentik dapat dengan berbagai cara. Untuk membuat suatu akta otentik, pada umumnya notaris akan menyarankan menghadirkan mantan pasangan kawin. Bila hal tersebut tidak dapat dilakukan karena satu dan lain hal maka dapat dilakukan dengan persetujuan tertulis.

Dalam Perjanjian Pengikatan

Jual Beli dalam Putusan ini, Pihak Penjual dalam Perjanjian Pengikatan Jual Beli dalam melakukan perbuatan hukum mengalihkan hak atas tanah yang merupakan harta bersama memerlukan persetujuan Tergugat I

${ }^{13}$ Wawancara dengan Tuan Z, Notaris pembuat Akta Perjanjian Pengikatan Jual Beli Pada 6 Mei 2021 di Kabupaten Sleman. sebagai mantan pasangan kawin. Sebagai dasar kewenangan bertindaknya, Pihak Penjual dalam Perjanjian Pengikatan Jual Beli dan Tergugat I membuat Surat Perjanjian tertanggal 18 Februari 2017 yang mana surat tersebut dititipkan kepada Notaris yang berkedudukan di Banyumas sebagaimana yang dinyatakan dalam Akta Van Depot tanggal 21 Agustus 2018.

\section{Pertanggungjawaban}

Notaris

Terhadap Akta Perjanjian Pengikatan Jual Beli Yang Dibuat Di Hadapannya

Narasumber Notaris Agung Herning Indradi Prajanto S.H. M.Hum menyatakan 14 Notaris dalam melaksanakan tugas dan kewajibannya tunduk pada UUJN serta UUJNP. UUJN serta UUJNP merupakan hukum tertulis yang berlaku pula

14 Wawancara dengan Notaris Agung Herning Indradi Prajanto S.H. M.Hum, pada tanggal 7 Juni 2021, di Kantor Notaris/ PPAT Agung Herning Indradi Prajanto S.H. M.Hum di Perumahan Soka Asri Blok O-7 Purwomartani, Kalasan, Kabupaten Sleman, Daerah Isimewa Yogyakarta. 
sebagai alat ukur bagi notaris dalam

menjalankan tugas dan jabatannya.

Kewenangan notaris sebagai pejabat

umum diatur dalam Pasal 15 UUJNP.

Dalam menjalankan kewenangannya

tersebut notaris wajib tunduk pada

Pasal 16 UUJNP.

Tanggungjawab notaris selaku pejabat umum meliputi tanggung jawab profesi notaris itu sendiri yang berhubungan dengan akta. Tanggungjawab ini dibedakan dalam: 15

a. Tanggungjawab notaris secara perdata

Menurut responden Notaris pembuat Akta Perjanjian Pengikatan Jual Beli, tanggungjawab notaris secara perdata ialah tanggung jawab terhadap kebenaran tanggal pembuatan suatu akta serta keberanan formil dokumen para

15 Abdul Ghofur Anshori, 2009, Lembaga kenotariatan Indonesia Prespektif Hukum dan Etika, UII Press, Yogyakarta, hlm.34 pihak dalam kontruksi perbuatan melawan hukum. Suatu perbuatan dikategorikan sebagai perbuatan melawan hukum apabila perbuatan tersebut:

1) Melanggar hak orang lain;

2) Bertentangan dengan aturan hukum

3) Bertentangan dengan kesusilaan

4) Bertentangan dengan kepatutan dalam memperhatikan kepentingan diiri dan harta orang lain dalam pergaulan hidup sehari-hari.

Perbuatan melawan hukum disini dapat pula diartikan dalam sifat aktif maupun pasif. Sifat aktif dalam artian melakukan perbuatan yang menimbulkan kerugian pada pihak lain. Sifat pasif dalam artian tidak melakukan perbuatan yang merupakan keharusan, sehingga 
pihak lain menderita kerugian.

Jadi unsur dari perbuatan

melawan hukum disini yaitu adanya kesalahan dan adanya

kerugian yang ditimbulkan.

Menurut narasumber Notaris

Agung Herning Indradi Prajanto

S.H. M.Hum ${ }^{16}$ dan Notaris

Asnahwati H. Herwidi, S.H.

menyatakan, ${ }^{17}$ bahwa pada

dasarnya Notaris tidak

bertanggung jawab terhadap isi

akta yang dibuat di hadapannya.

Isi akta merupakan kehendak dan

kesepakatan yang diinginkan oleh

para pihak. Notaris hanya

menuangkan kesepakatan tersebut

kedalam bentuk akta otentik

sehingga dalam hal ini Notaris

hanya bertanggung jawab

16 Wawancara dengan Notaris Agung Herning Indradi Prajanto S.H. M.Hum, pada tanggal 7 Juni 2021, di Kantor Notaris/ PPAT Agung Herning Indradi Prajanto S.H. M.Hum di Perumahan Soka Asri Blok O-7 Purwomartani, Kalasan, Kabupaten Sleman, Daerah Isimewa Yogyakarta.

17 Kunni Afifah, "Tanggung Jawab dan Perlindungan Hukum bagi Notaris secara Perdata Terhadap Akta yang dibuatnya", Jurnal lex Renaissance, Fakultas Hukum Universitas Islam Indonesia, No.1, Vol 2, Januari, 2017, hlm. 154. terhadap bentuk formal akta

otentik sebagaimana yang

ditetapkan oleh undang-undang.

b. Tanggungjawab notaris secara pidana.

Pidana dalam hal ini adalah perbuatan pidana yang dilakukan oleh seorang notaris dalam kapasitasnya sebagai pejabat umum yang berwenang membuat akta, bukan dalam konteks individu sebagai warga negara pada umumnya. Pertanggungjawaban pidana lahir dengan diteruskannya celaan (verwijbaarheid) yang obyektif terhadap perbuatan yang dinyatakan sebagai tindak pidana berdasarkan hukum pidana yang berlaku (terpenuhinya unsur delik), dan secara subyektif kepada pelaku yang memenuhi persayaratan untuk 
dapat dikenakan pidana karena perbuatannya itu. ${ }^{18}$

c. Tanggungjawab notaris secara administrasi

Berdasarkan Pasal 16 ayat (11) UUJNP terdapat 4 (empat) jenis sanksi administrasi yang diberikan apabila seorang notaris melanggar ketentuan dalam UUJN dan UUJNP. Sanksi tersebut antara lain peringatan tertulis, pemberhentian sementara, pemberhentian dengan hormat, pemberhentian tidak hormat. Selain sanksi sebagaimana dinyatakan dalam Pasal 16 ayat (11) tersebut, bagi pihak yang menderita kerugian dapat menuntut penggantian biaya, ganti rugi, dan bunga kepada notaris.

\section{Perlindungan hukum terhadap} pihak pembeli yang beriktikad baik dalam perjanjian pengikatan jual

18 Dwidja Priyatno, 2004, Kebijakan Legislasi tentang Sistem Pertanggungjawaban Pidana Korporasi di Indonesia, CV. Utomo, Bandung, hlm. 30

\section{beli yang objeknya merupakan}

\section{harta bersama}

Suatu perjanjian tentu tidak selamanya dapat berjalan dengan baik. Perjanjian dalam pelaksanaannya memungkinkan untuk tidak terlaksana atau tidak sempurna, baik karena kesalahan maupun karena kekuatan memaksa (overmacht). Adakalanya perjanjian tidak terlaksana sepenuhnya seperti yang disepakati bahkan perjanjian dapat tidak terlaksana sama sekali.

Responden Notaris pembuat Akta Perjanjian Pengikatan Jual Beli menyatakan bahwa terdapat tiga tahap pembuatan perjanjian yaitu sebelum pembuatan perjanjian, pada saat pembuatan perjanjan dan pelaksanaan perjanjian. Notaris sebagai pejabat umum memiliki kewajiban memberikan perlindungan hukum pada tahapan sebelum pembuatan perjanjian dan pada saat pembuatan 
perjanjian. ${ }^{19}$ Menurut Narasumber Notaris Agung Herning Indradi

Prajanto S.H. M.Hum, meskipun

Notaris tidak memiliki kewajiban untuk memberikan perlindungan hukum bagi para pihak pada tahapan pelaksanaan perjanjian, namun guna melaksanakan prinsip kehati-hatian Notaris berhak untuk membuat Akta Kuasa Menjual dari penjual kepada pembeli yang beritikad baik. ${ }^{20}$

Dalam Putusan Pengadilan Negeri Sleman Nomor 221/Pdt.G/2019/Pn.Smn serta berdasarkan hasil wawancara, Pembeli menyatakan bahwa Notaris pembuat Akta Perjanjian Pengikatan Jual Beli telah menyarankan menyertakan Akta Kuasa Menjual yang dibuat oleh para pihak di hadapan Notaris. Maka dari itu seketika setelah ditandatanganinya

${ }^{19}$ Wawancara dengan Tuan Z, Notaris pembuat Akta Perjanjian Pengikatan Jual Beli Pada 6 Mei 2021 di Kabupaten Sleman.

20 Wawancara dengan Notaris Agung Herning Indradi Prajanto S.H. M.Hum, pada tanggal 7 Juni 2021, di Kantor Notaris/ PPAT Agung Herning Indradi Prajanto S.H. M.Hum di Perumahan Soka Asri Blok O-7 Purwomartani, Kalasan, Kabupaten Sleman, Daerah Isimewa Yogyakarta.
Akta Perjanjian Pengikatan Jual Beli, para pihak membuat Akta Kuasa Menjual. $^{21}$

\section{Berdasarkan Surat Edaran} Mahkamah Agung (SEMA) Nomor 4 Tahun 2016 mengenai kriteria pembeli yang beritikad baik, Pembeli dalam Akta Perjanjian Pengikatan Jual Beli ini telah memenuhi ktiteria sebagai pembeli yang beritikad baik. Hal ini dikarenakan pembeli telah memastikan bahwa penjual merupakan pemilik hak atas tanah sebagai mana dinyatakan dalam sertipikat hak milik. Ditinjau berdasarkan kewenangan melakukan perjanjian, Pihak Penjual dalam Perjanjian Pengikatan Jual Beli telah mendapat persetujuan dari Tergugat I selaku mantan pasangan kawin sebagaimana dituangkan dalam Surat Perjanjian tertanggal 18 Februari 2017 yang mana surat tersebut dititipkan

21 Wawancara dengan Tuan X selaku pihak pembeli dalam Perjanjian Pengikatan Jual Beli yang juga merupakan Pengguggat dalam Putusan Pengadilan Negeri Sleman Nomor 221/Pdt.G/2019/Pn.Smn. 
kepada Notaris yang berkedudukan di Banyumas.

Sebagai pemilik hak atas tanah, pembeli yang bertikad baik sudah seharusnya dilindungi oleh undangundang. Hal tersebut sesuai dengan tujuan pendaftaran tanah yang dinyatakan dalam Pasal 19 UUPA. Maka dari itu, penyelenggaraan pendaftaran tanah kemudian diatur dalam Peraturan Pemerintah Nomor 10 tahun 1961 tentang Pendaftaran Tanah, Namun dalam pelaksanaannya Peraturan Pemerintah ini masih memiliki beberapa kekurangan. Untuk menyempurnakan peraturan tersebut, pemerintah menerbitkan Peraturan Pemerintah Nomor 24 tahun 1997 tentang Penyelenggaraan Pendaftaran tanah.

Pasal 32 ayat (1) Peraturan Pemerintah Nomor 24 Tahun 1997 menyatakan bahwa "Sertipikat merupakan tanda bukti hak yang berlaku sebagai alat pembuktian yang kuat mengenai data fisik dan data yuridis yang termuat di dalamnya, sepanjang data fisik dan data yuridis tersebut sesuai dengan yang ada dalam surat ukur dan buku tanah yang bersangkutan". Ketentuan tersebut mengandung makna bahwa selama belum dibuktikan yang sebaliknya, data fisik dan data yuridis yang dicantumkan dalam sertipikat harus diterima sebagai data yang benar, baik dalam perbuatan hukum sehari-hari maupun dalam sengketa di Pengadilan, sepanjang data tersebut sesuai dengan apa yang tercantum dalam surat ukur dan buku tanah yang bersangkutan.

Berdasarkan Pasal 32 ayat (2)

Peraturan Pemerintah Nomor 24 Tahun 1997 tentang Pendaftaran Tanah dapat diartikan bahwa bentuk perlindungan hukum yang diberikan oleh negara ialah dengan adanya sistem pembuktian negatif bertendensi positif. Maksud dari sistem publikasi 
negatif bertendensi positif adalah

sistem pendaftaran tanah ini

menggunakan sistem pendaftaran hak

(sistem Torrens / registration of

titles), tetapi sistem publikasinya

belum dapat positif murni. Hal ini

dikarenakan, data fisik dan data

yuridis dalam sertipikat tanah belum

pasti benar, meskipun harus diterima

oleh Pengadilan sebagai data yang

benar selama tidak ada alat

pembuktian yang membuktikan

sebaliknya. ${ }^{22}$ Berdasarkan sistem

publikasi tersebut maka pihak yang

menyangkal kebenaran sertipikat hak

atas tanah memiliki kewajiban

membuktikan ketidakabsahan

sertipikat hak atas tanah tersebut.

Realitanya untuk mendapat

perlindungan hukum dari kekuasaan

negara melalui proses peradilan dari

tingkat pertama, tingkat banding

${ }^{22}$ Novina Sri Indirahati, Peneratapn Sistem Torrens dalam Pendaftaran Tanah (Studi Komparatif terhadap Sistem Pendaftaran Tanah di Indonesia dengan Singapura), Jurnal Clavia, Edisi No.1, Vol.10, 2009, hlm.109. sampai dengan tingkat kasasi

memerlukan waktu yang cukup lama.

\section{Penutup}

\section{Kesimpulan}

a. Akta Perjanjian Pengikatan Jual Beli yang objeknya merupakan harta bersama dalam Putusan Pengadilan Negeri Sleman Nomor 221/Pdt.G/2019/Pn.Smn sah karena telah memenuhi ketentuan dalam Pasal 1320 KUHPerdata. Akibat hukum dari perjanjian ini ialah perjanjian mengikat bagi para pihak dan menyebabkan para pihak yang terikat memiliki hak dan kewajiban yang harus dilaksanakan.

b. Terhadap akta perjanjian pengikatan jual beli yang objeknya merupakan harta bersama yang dibuat di hadapannya notaris memiliki tanggung jawab secara perdata, pidana dan administrasi. Notaris hanya 
memiliki tanggung jawab atas formalitas dari suatu akta otentik dan tidak memiliki tanggung jawab atas materi dari isi akta otentik itu kecuali pada relass akta. Terhadap akta yang bersifat mengalihkan hak milik benda yang merupakan harta bersama notaris memiliki kewajiban memastikan keabsahan kesepakatan untuk mengalihkan harta bersama dari mantan pasangan kawin pihak penjual. Notaris hanya dapat dimintakan pertanggungjawaban apabila Notaris terbukti melakukan pelanggaran administrasi, perdata dan pidana.

c. Perlindungan hukum terhadap pihak pembeli yang beriktikad baik dalam perjanjian pengikatan jual beli yang objeknya merupakan harta bersama ialah dengan dibuatkannya akta kuasa menjual oleh notaris dan pihak pembeli memiliki hak untuk mengajukan gugatan terhadap akta perjanjian pengikatan jual beli dimuka pengadilan.

\section{Saran}

Berdasarkan uraian hasil analisis penulis, adapun saran yang dapat diberikan berdasarkan kesimpulan diatas ialah:

a. Bagi pemerintah untuk membuat suatu aturan khusus (lex spesialis) mengenai kriteria bentuk kesepakatan oleh mantan pasangan kawin untuk mengalihkan hak atas benda tidak bergerak yang merupakan objek harta bersama.

b. Bagi Notaris dalam menjalankan tugas dan kewenangannya perlu memperhatikan prinsip kehatihatian serta aktif memberikan penyuluhan hukum kepada masyarakat mengenai 
kewajiban para pihak serta

akibat yang akan timbul dari

dibuatnya perjanjian

pengikatan jual beli tersebut.

c. Bagi masyarakat yang ingin membeli hak atas tanah dan / atau bangunan sebaiknya menerapkan prinsip kehatihatian dengan memeriksa obyek tanah dengan teliti agar tidak terjadi hal-hal yang tidak diinginkan dikemudian hari. Hal ini bertujuan agar ketika perjanjian pengikatan jual beli tanah telah dibuat dan prestasi telah dilaksanakan oleh pihak pembeli, tidak ada gangguan dari pihak lain

\section{Daftar Pustaka}

\section{Buku}

Anshori, Abdul Ghofur, Lembaga kenotariatan Indonesia Prespektif Hukum dan Etika, UII Press, Yogyakarta, 2009.

Ashofa, Burhan, Metode Penelitian Hukum, Cetakan ke-4, Rineka Cipta, Jakarta, 2004.
Muhammad, Abdulkadir, Hukum dan Penelitian Hukum, Cetakan ke1, PT Citra Aditya Bakti, Bandung, 2004.

Patahna, Muchlis, Problematika Notaris, Rajawali, Jakarta, 2009.

Priyatno, Dwidja, Kebijakan Legislasi tentang Sistem Pertanggungjawaban Pidana Korporasi di Indonesia, CV. Utomo, Bandung, 2004.

Soekanto, Soerjono dan Sri Mamudji, Penelitian Hukum Normatif Suatu Tinjauan Singkat, PT Raja Grafindo Persada, Jakarta, 2014.

Susanto, Happy, Pembagian Harta Bersama Saat Tejadi Perceraian, Cetakan Kedua, Visi Media, Jakarta, 2008.

\section{Artikel / Jurnal}

Afifah, Kunni, "Tanggung Jawab dan Perlindungan Hukum bagi Notaris secara Perdata Terhadap Akta yang dibuatnya", Jurnal lex Renaissance, Fakultas Hukum Universitas Islam Indonesia, No.1, Vol 2, Januari, 2017.

Budiono, Herlien, "Pengikat Jual Beli Dan Kuasa Mutlak", Artikel Majalah Renvoi, edisi Tahun I, No 10, Bulan Maret, 2004.

Indirahati, Novina Sri, Penerapan Sistem Torrens dalam Pendaftaran Tanah (Studi Komparatif terhadap Sistem Pendaftaran Tanah di Indonesia dengan Singapura), Jurnal Clavia, Edisi No.1, Vol.10, 2009. 
Nagara, Bernandus, "Pembagian Harta Gono Gini atau Harta Bersama Setelah Perceraian Menurut Undang-Undang Nomor 1 Tahun 1974", Jurnal Lex Crimen, Vol. V, No.7, Sept, 2016.

\section{Peraturan Perundang-undangan}

Kitab Undang-Undang Hukum Perdata (Burgerlijk Wetboek).

Undang-Undang Nomor 1 Tahun 1974 Tentang Perkawinan.

Peraturan Pemerintah Nomor 24 Tahun 1997 tentang Pendaftaran Tanah. 